\title{
Classical approaches to development: Modernisation and dependency
}

Wil Hout

\section{Introduction}

Writing in the first half of the 1980s, Richard Higgott (1983: vii) described modernisation and dependency approaches as 'the two dominant perspectives on political and social change in the Third World'. Higgott was able to capture the main elements of the debate in a book of approximately 120 pages. If he were writing his book today, the proliferation of research in and theorising on development issues, both in and beyond the Global South, would surely take Higgott far beyond the classical theories of development, and would require a much longer manuscript.

A proper understanding of the classical theories is still useful for contemporary researchers on international development. This is the case not only because researchers need to know about the antecedents of the intellectual field they work in, but also because the modernisation and dependency approaches have had important influences on more recent theorising, and because the classical theories 'live on' in contemporary studies of issues such as democratisation, identity and global production.

Modernisation and dependency theories represent two rather different points in the spectrum of approaches to international development. Also politically, the two theoretical positions have pointed at fundamentally different strategies for the improvement of the situation in developing countries. Yet, at the same time, modernisation and dependency approaches have important features in common. In the first place - and this is the more important in the light of critiques of the linearity assumption in development theorising voiced in recent decades - the two approaches share the conviction that development is essentially a process that is able to bring about progress. In the second place, the approaches clearly focus on 'macro-structures' (Nederveen Pieterse, 2010: 12) in their explanation of development and the barriers to development

This chapter addresses various dimensions of the classical theories of development. Sections 2 and 3 discuss the main features of the two classical approaches to development, 
modernisation and dependency theory. Sections 4 and 5 present some examples of the way in which the classical approaches are manifested in contemporary thinking about development. Section 6 contains some brief concluding remarks.

\section{The modernisation approach}

The modernisation approach took an important lead from the classical concern of Western thought with notions of social, economic and political transformation. In his classical analysis of the sociological tradition, Nisbet (1966: viii) traced back the inspiration of the great social theorists of the nineteenth and early twentieth century to 'the conflicts between traditionalism and modernism in European culture'.

An important inspiration for modernisation theory derived from the work of American sociologist Talcott Parsons. Parsons, whose sociological theory is often labelled as structuralfunctionalist, focused on the evolution of societies from 'traditional' to 'modern' forms. ${ }^{1}$ Parsons' evolutionary approach of social change draws on biological analogies and revolves around the notion of adaptation, or the capacity of a social system to respond to changes in its environment (Parsons, 1964: 340). Parsons posited that societies that are able to adapt successfully to changes in the environment, notably to fundamental long-term changes of the magnitude of the Industrial and French Revolutions, demonstrate certain 'evolutionary universals'. In his own words,

An evolutionary universal, then, is a complex of structures and associated processes the development of which so increases the long-run adaptive capacity of living systems in a given class that only systems that develop the complex can attain certain higher levels of general adaptive capacity. (Parsons, 1964: 340-341)

The evolutionary universals that Parsons (1964: 342-350) distinguished, were: social stratification, cultural legitimation, bureaucratic organisation, and money and markets. The conclusion that he arrived at was that societies are better able to adapt to change to the extent they have developed more complex social hierarchies (going beyond the 'two-class system' of rulers vs. ruled), more elaborate ways of legitimation of the rulers, more effective bureaucracies, and better functioning markets and monetary systems.

\footnotetext{
${ }^{1}$ The most important works by Parsons include his The Social System (Parsons, 1951) and Structure and Process in Modern Societies (Parsons, 1960).
} 
The distinction between the 'traditional' and the 'modern' became the hallmark of modernisation theory. Contributions to the approach were decisively multidisciplinary, and derived from most of the social sciences, including sociology, economics, political science and anthropology. The analytical categories of 'traditional' (or 'simple') and 'modern' (or 'complex') showed a clear resemblance to 'Western' and 'non-Western' forms of social, political and economic organisation. For this reason, modernisation theory was often criticised for its normativity - as essentially being an ethnocentric representation of Western values (e.g., Nederveen Pieterse, 2010: 23; Frank, 1969: 21-95). Various critics of the modernisation approach made a connection between the ideas that were produced and the role these played during the Cold War era (e.g., Nederveen Pieterse, 2010: 23; Ross, 1998).

Among the great variety of authors who contributed to modernisation theory, economist Walt W. Rostow stands out. In his classic The Stages of Economic Growth, Rostow distinguished five stages ranging from traditional to modern ('mass-consumption') societies, on the basis of an 'analytic bone-structure', determined by production relations, more specifically 'the distribution of income between consumption, saving, and investment ... the composition of investment and ... developments within particular sectors of the economy' (Rostow, 1960: 13). Traditional societies are characterised by the dominance of agricultural production and limited productivity. The preconditions for take-off, Rostow's second stage, result from scientific innovations, which lead to surpluses that can be used for investment. The take-off stage is a phase of self-sustained growth, when manufacturing, initiated by an entrepreneurial elite, becomes the driving force of development. The drive to maturity leads to the replacement of original growth sectors by new ones, such as heavy industry during the Industrial Revolution of the $18^{\text {th }}$ and $19^{\text {th }}$ centuries in Europe. The age of high massconsumption, Rostow's final stage, leads to an emphasis on consumption rather than production (Rostow, 1960: 17-92).

Bert F. Hoselitz used the concept of 'pattern variables', ${ }^{2}$ derived from Parsons (1951), in his sociological analysis of economic development. Hoselitz, together with Rostow one of the main targets of Andre Gunder Frank's critique of modernisation theory (Frank, 1969: 24-47), emphasised that the increasing complexity of the division of labour is the main reflection of economic development. In terms of the pattern variables, Hoselitz (1960: 47) argued that 'The very needs of economic advancement must bring about a gradual replacement of

\footnotetext{
${ }^{2}$ The pattern variables distinguished by Parsons were: universalism vs. particularism, ascription vs. achievement, orientation towards the collective vs. self-orientation, and diffuseness vs. specificity and neutrality vs. affectivity (Parsons, 1951: 105).
} 
ascription as a standard by achievement, and associated with this a replacement of functional diffuseness by functional specificity and particularism by universalism'.

In addition to economists and sociologists, political scientists contributed significantly to modernisation theory. Among the most influential contributions in the early phase of the modernisation approach was an edited volume by Almond and Coleman (1960) on the politics of the developing areas. The volume started from the functions performed by structures in political systems 'in all societies regardless of scale, degree of differentiation, and culture' (Almond, 1960: 5). The functional categories distinguished by Almond (1960: 17) included four input functions (political socialisation and recruitment, interest articulation, interest aggregation and political communication) and three output functions (rule-making, rule application and rule adjudication). This approach to political modernisation assumes that a single political structure - such as a ruler, a legislature or a bureaucracy - can perform multiple functions. Yet, the approach argues that 'modern' political systems are characterised by structural differentiation or specialisation, implying that political structures are increasingly seen to perform only a single function:

What we mean when we speak of modern systems as being specialized is that certain structures emerge which have a functional distinctiveness, and which tend to perform what we may call a regulatory role in relation to that function within the political system as a whole. ... What is peculiar to modern political systems is a relatively high degree of structural differentiation (i.e., the emergence of legislatures, political executives, bureaucracies, courts, electoral systems, parties, interest groups, media of communication), with each structure tending to perform a regulatory role for that function within the political systems as a whole. (Almond, 1960: 18).

Authors contributing to a second wave of modernisation theory, the beginning of which is usually dated in the second half of the 1960s, were, in Higgott's (1983: 18) assessment, overall less optimistic about the prospects for progress and democracy than modernisation theorists in the first half of the decade. Samuel Huntington's work on political order was the prime example of the emergent concern with political stability. Huntington focused on the existence of a 'political gap' between more and less developed countries in terms of the level of political institutionalisation, in parallel to the more evident difference in levels of economic development. According to him, political violence and instability 'was in large part 
the product of rapid social change and the rapid mobilization of new groups into politics coupled with the slow development of political institutions' (Huntington, 1968: 4).

In Huntington's view, many developing countries experience a growing problem of political institutionalisation as a result of contrary movements of social mobilisation and economic development. Social mobilisation - 'a change in the attitudes, values and expectations of people from those associated with the traditional world to those common to the modern world' (Huntington, 1968: 38) - leads to wants and aspirations among developing country populations that cannot be satisfied given the level of economic development. The frustration that is induced by the growing disparity between social mobilisation and economic possibilities leads to increased pressure on the political system to deliver, in the form of enhanced political participation. The strength of political institutions is key to dealing with this pressure: in Huntington's interpretation, political systems that are more successful in developing strong institutions can deal better with the increasing pressure generated by political participation and will turn out to be more stable. Political instability is likely to emerge when political institutions are not able to cope with increased participation (Huntington, 1968: 78-92).

Modernisation theory came under increasing attack in the second half of the 1960s. Apart from the criticism targeted at the approach's ethnocentrism that was signalled above, critics increasingly pointed at the neglect of influences deriving from the role and position of developing countries in the international system. Analysts of economic underdevelopment of countries in Latin America, in particular, referred to the impact of colonialism and economic dependence on the United States as major sources of distorted development. The analysis of underdevelopment and dependence gave rise to a an understanding of development that was generalised in dependency theory, the second classical approach to development that is discussed in this chapter.

\section{The dependency approach}

In a similar way as the modernisation approach was inspired by nineteenth- and earlytwentieth-century social theorists who focused on the roots of European social and economic modernity, many dependency theorists continued the radical tradition that was set in by Marxist and neo-Marxist analyses of capitalism and imperialism in the same epoch. Central ideas derived by dependency (and later by world-system) theory from the (neo-)Marxist tradition concern the imperative of capital accumulation as an element of the capitalist political-economic order, and the inherently exploitative nature of relations of production 
Dependency theory originated in the Latin America of the 1960s, and built on earlier structuralist work on development pioneered by Raúl Prebisch and others in the Economic Commission for Latin America (ECLA) in the late 1940s and early 1950s (Kay 2011: 117). As analysed by Kay (2011: 117-118) in his classical work on Latin American theories of development and underdevelopment, Latin American dependency theory consisted of two positions: reformist and Marxist. The reformist position is reflected in the work of authors such as Fernando Henrique Cardoso, Enzo Faletto, Celso Furtado and Osvaldo Sunkel, while Marxist-inspired dependency theorists include Andre Gunder Frank, Theotonio dos Santos and Ruy Mauro Marini. Although the reformist position was significant from an academic/analytical point of view, the Marxist position obtained more widespread international appeal and was generalised to a more general theory of development by including perspectives from Africa and Asia through the work of scholars such as Samir Amin and Walden Bello.

The reformist position was epitomised in Cardoso's (1972) analysis of dependent capitalist development and Cardoso and Faletto's (1979) seminal work on dependency and development in Latin America. The analysis put forward in these reformist works focused on the change in the nature of dependency, away from the simple exchange of primary products for manufactured ones, to a situation in which industrial production for the market in Latin America became more important. There would be a continuation of dependency, as in Cardoso's words:

in spite of internal economic development, countries tied to international capitalism by that type of linkage remain economically dependent, insofar as the production of the means of production (technology) are concentrated in advanced capitalist economies (mainly in the US).... Some degree of local prosperity is possible insofar as consumption goods locally produced by foreign investments can induce some dynamic effects in the dependent economies. But at the same time, the global process of capitalist development determines an interconnection between the sector of production of consumption goods and the capital goods sector, reproducing in this way the links of dependency. (Cardoso, 1972: 90-91)

A key element in this work is the notion that dependency cannot be understood solely as a characteristic of the external environment of developing countries, but that the internal dynamics needs to receive equal attention for understanding the historical dynamics of 
relations between countries from the centre and those in the periphery: Cardoso and Faletto (1979: xvi) place emphasis on the importance of understanding 'the social practices of local groups and classes which try to enforce foreign interests, not precisely because they are foreign, but because they may coincide with values and interests that these groups pretend are their own'.

The dominant position within the dependency approach has undoubtedly been the Marxistinspired interpretation, which emphasised the impact of the outward-oriented nature of developing countries. Within the Marxist tradition of dependency, Andre Gunder Frank became a leading figure, emphasising the 'development of underdevelopment'. Frank's work is built on the difference between the experience of Western and developing countries - this is reflected in his famous formulation, 'The now developed countries were never underdeveloped, though they may have been undeveloped' (Frank 1969:4).

Andre Gunder Frank (1969: 9) analysed development and underdevelopment as 'opposite sides of the same coin', as the outcome of the history of the capitalist world system. According to Frank, the driving force of global capitalism has always been exploitation: of the working class by the capital owners, and of the countries of the periphery by those in the centre. The bourgeoisie in peripheral countries share in the benefits of exploitation of their own population through their links to the centre, but is essentially a 'lumpenbourgeoisie' that is fully dependent on forces in the centre of the world system (Frank 1972: 13-14).

In Frank's analysis, the capitalist world system, which originated in the fifteenth century, revolves around the logic of capital accumulation. Through unequal trade, investment and labour relations, the centre has been able to syphon off economic surpluses from the periphery. The main mechanisms of surplus extraction have changed over the history of capitalism. The classical colonial relationship between the centre and the periphery concerned trade in raw materials produced by the colonies for manufactured goods produced by the colonial powers of Europe (Frank, 1979: 103-110). Next to this, investments have been a second means of surplus extraction: capital owners ensure that the benefits of the investments flow back to the centres of capitalism, which implies that the benefits for the periphery are minimal (Frank, 1979: 189-199). Labour has been incorporated into the production process at adverse terms throughout the history of capitalism. Various forms of forced labour, including slavery during the first few centuries of capitalist history, were succeeded by proletarianisation and informalisation of labour in different parts of the world (Frank, 1979: 160-171). 
In similar ways as Andre Gunder Frank but with different emphases, Egyptian-born Samir Amin (1974) analysed issues of dependence and (under)development in terms of 'accumulation on a world scale'. In his view, the expansion of capitalism over the past five centuries has been the consequence of falling rates of profit in the centre of the capitalist world system. The centre and periphery of the capitalist system are linked through mechanisms of 'unequal exchange' of different types of commodities, while those mechanisms are based on the unequal remuneration of labour in the various parts of the system (Amin, 1974: 62-63). In Amin's view, unequal exchange leads to a transfer of value from the periphery to the centre in the form of undervalued commodities and manufactured goods 'traded' between both poles of the system. Underdevelopment in the periphery is manifested in three main structural features (Amin, 1974: 262-299): the existence of extreme disparities in productivity across sectors in the periphery; the absence of linkages ('disarticulation') among productive sectors in the periphery and, instead of these, the outward orientation to meet demands from the centre; and the highly unequal international division of labour, reflected in 'unequal specialisation' and the periphery's dependence on foreign capital.

Frank and Amin reached similar conclusions from their analysis for the political strategies of developing countries. The notion of 'dissociation' of developing countries from the world system that Frank (1984: 215-229) proposed closely resembled Amin's (1987; 1990) ideas of 'delinking'. Amin's proposal to delink developing countries from the world system derived from his understanding that development policies can only be beneficial for developing countries if they are truly 'autocentric'. Developing countries' export orientation would need to be reversed and instead of producing mainly primary products for world markets, they should steer their economies toward the production of goods for consumption and capital goods (Amin, 1990: 18-19). The proposal for delinking involved a political programme, as 'delinking, whether one likes it or not, is associated with a "transition" - outside capitalism and over a long time - towards socialism' (Amin, 1990: 55).

Since the early 1970s, world-system ${ }^{3}$ theory started to emerge in an attempt by Immanuel Wallerstein and several dependency theorists to develop a social-scientific interpretation of the history of the capitalist world-system. The world-system approach gradually occupied the

\footnotetext{
${ }^{3}$ Wallerstein started to use the term world-system (instead of world system) theory to reflect Fernand Braudel's (1992: 22) usage of 'économie monde' (world-economy) as something different from 'économie mondiale' (world economy), where the former notion denotes an part of the world that is economically autonomous and characterised by a single division of labour.
} 
place of dependency theory. Wallerstein's historical-sociological interpretation of the rise and expansion of the capitalist world-economy since the 'long sixteenth century' (1450-1600) revolves around the notion of the single division of labour.

According to Wallerstein, the focus of theories of long-term development should not be on societies or polities, but rather on 'social systems'. As he phrased it himself, 'My own unit of analysis is based on the measurable social reality of interdependent productive activities, what may be called an "effective social division of labor" or, in code language, an "economy" (Wallerstein, 1984: 2). The history of the capitalist world-economy, in Wallerstein's view, is the history of the expansion of the global division of labour, which has integrated all parts of the world and reached its peak in the period of neoliberal globalisation (Wallerstein, 2000). Capital accumulation has always been the main drive of capitalists worldwide, and the main political strategy to continue the deepening of this process has been 'the relocation of given sectors of production to other zones of the world economy that are, on the average, lower-wage areas' (Wallerstein, 2000: 261).

The history of the modern world-system, which has been a capitalist world-economy, has seen the decline of accumulation mechanisms other than the production for (world) markets. Politically, the world-economy has been able to survive despite the fundamental contradictions and tensions among social groups thanks to the fact that the global division of labour was never controlled by one political entity - which would, in Wallerstein's words, have turned the world-economy into a world-empire (Wallerstein, 1974: 347-348). An important element in the political organisation of the modern world-system has been the middle tier of areas between the core and the periphery: the semiperiphery. The semiperiphery, which is 'both exploited and exploiter' (Wallerstein, 1979: 23), is understood in terms of its middle position in relation to such features as the capital intensity of production, the mode of labour control and the strength of the state. The role of the semiperiphery is seen mainly in political terms, in that it consists of 'middle areas [that] partially deflect the political pressures which groups primarily located in peripheral areas might otherwise direct against core-states and the groups which operate within and through their state machineries' (Wallerstein, 1974: 350).

Throughout their history, dependency and world-system theories have been criticised for their emphasis on the material and economic dimensions of their explanatory model, as well as for the seemingly deterministic nature of the explanations of development processes. Other approaches, such as post-colonial theory and post-structuralism, have been formulated by 
scholars who have an affinity with the radical criticism of dependency but stress other dimensions of development, such as culture and identity issues.

\section{Contemporary manifestations of the modernisation approach}

The criticism aimed at modernisation theory since the second half of the 1960s did diminish the appeal of this approach to development, but has not led to its complete demise. Although the heydays of modernisation theory are long past, many scholars have remained inspired by notions that were brought forward as part of the theorisation of modernity and tradition. In most cases, the ideas of modernisation theory were not followed uncritically, so that more recent manifestations of the thinking on modernity and tradition have incorporated part of the criticism levelled at the approach. Four examples of the influence of modernisation theory are discussed in this section: the work of Ronald Inglehart on democracy and democratisation, reflections by Shmuel Eisenstadt on multiple modernities, Ian Buruma and Avishai Margalit's interpretation of occidentalism, and North et al.'s work on social order and economic development.

American political scientist Ronald Inglehart has contributed importantly to research on the changes in social and political values that are brought about by processes of industrialisation. Since the early 1970s, Inglehart has been a proponent of the view that industrialisation and increased wealth bring about a change in value orientation of younger generations that sets these apart from the older ones. Analysing data from the advanced industrialised countries, Inglehart showed that older generations typically place more emphasis on so-called 'acquisitive priorities', linked to law and order, stability and material wealth, while younger ones adopted 'post-bourgeois' or 'post-materialist' values, related to freedom of expression and political participation (Inglehart, 1971: 994-996). Inglehart concluded that the embrace of post-materialist issues by certain, newer political parties would likely lead to a 'silent revolution' in advanced democracies, as the changed preferences of younger groups of voters would strengthen the post-materialist parties and erode the support base of traditional parties (Inglehart, 1971: 1009-1013). In later work, based on the World Values Surveys, Inglehart (1997: 4) argued that the shift from materialist to post-materialist values was only one element of a broader cultural change, involving a range of orientations from religious beliefs to sexual norms. The inspiration he has taken from modernisation theory becomes clear in his position that '[e]conomic development, cultural change, and political change go together in coherent and roughly predictable patterns' (Inglehart, 1997: $324)$. 
In an attempt to broaden the analysis of modernisation and cultural change into 'new modernisation', Inglehart and Welzel (2009: 36) argued that democracy is the expected outcome of processes of social and economic modernisation. Focusing on modernisation as 'a syndrome of social changes linked to industrialization' (Inglehart and Welzel, 2009: 34), they posited that 'economic development brings social and political changes only when it changes people's behavior. Consequently, economic development is conducive to democracy to the extent that it, first, creates a large, educated, and articulate middle class of people who are accustomed to thinking for themselves and, second, transforms people's values and motivations' (Inglehart and Welzel, 2009: 42-43).

In his work on the impact of globalisation, sociologist Shmuel Eisenstadt has tried to come to grips with the nature of modernity in contemporary society. Taking issue with the position that modernisation would be akin to Westernisation, Eisenstadt (2002: 2-3) argued that 'Western patterns of modernity are not the only "authentic" modernities, though they enjoy historical precedence and continue to be a basic reference point for others'. According to Eisenstadt, the 'programme of modernity' consists of cultural, political and identity-related elements. The cultural dimension of modernity relates to ideas that human beings can shape their future through 'autonomous human agency' (Eisenstadt, 2002: 3) and are not limited in their action by traditional political and cultural relations of authority. The political element consists of the demise of traditional ways to legitimise the political order. The identity dimension of modernity is linked to the tendency to adopt more universalistic definitions of identity and collectivity.

Eisenstadt argued that modernity has taken different shapes in various parts of the world, among others under the influence of social movements (Eisenstadt, 2002: 9-12). As a result variants of modernity co-exist, and frequently conflict with each other. In particular, 'the encounter of modernity with non-Western societies brought about far-reaching transformations in the premises, symbols and institutions of modernity' (Eisenstadt, 2002: 14). The result of this development, according to Eisenstadt, was that multiple modernities have come into existence: these are modernities that share the elements of the abovementioned programme, but start from radically different values and therefore privilege contrasting political, cultural and social ordering principles. Referring to fundamentalist movements, Eisenstadt argued that these should often not be seen as traditionalist. Rather, 'the distinct visions of fundamentalist movements have been formulated in terms common to the discourse of modernity; they have attempted to appropriate modernity on their own terms' (Eisenstadt, 2002: 18). 
Buruma and Margalit (2004) have been inspired by modernisation theory in a different way than Eisenstadt. These authors have attempted to interpret variants of 'anti-Westernism' on the basis of the usage of modernity and modernisation as instruments in a political struggle. According Buruma and Margalit (2004: 3-10), so-called 'occidentalism' is spurred generally by the essentialisation of 'the West' in terms of certain features of modernity, such as industrialisation, urbanisation, democratisation and individualism, which are felt to run counter to the fundamental values held by the opponents. The anti-Westernism that was analysed by Buruma and Margalit (2004: 6-8) is not exclusively stemming from the nonWestern world: their example of German Nazism makes clear that the attack on Western values and ideas can also stem from within the West itself. Occidentalism, according to Buruma and Margalit, is not tied to any particular political position, as it may be embraced both by the left and the right. What unites the various occidentalist groups is their aversion to the modernity embodied by Western forms of social, cultural, economic and political life. The common method of occidentalists is to 'diminish an entire society or a civilization to a mass of soulless, decadent, money-grubbing, rootless, faithless, unfeeling parasites' (Buruma and Margalit, 2004: 10-11).

Grounded in the new institutional economics of development, North, Wallis and Weingast (2009) have worked out a 'conceptual framework' for the understanding of long-term socialeconomic change that is rooted North's earlier work, while also clearly taking inspiration from the tradition of modernisation theory. While the authors guarded against the simplistic developmentalism characteristic of earlier modernisation approaches - 'The dynamism of social order is a dynamic of change, not a dynamic of progress' (North et al., 2009: 12) -, the main categories of their thinking were the 'natural state' or 'limited access order' and the 'open access order'. The natural state is described as 'the default social outcome ... Until two hundred years ago, there were no open access orders; even today, 85 percent of the world's population live in limited access orders' (North et al., 2009: 13). Modernisation as a theoretical category comes in when North et al. (2009: 2) refer to ' $[t]$ he transition from the natural state to an open access order [as] the second social revolution, the rise of modernity'.

For North et al. (2009: 18-21, 30-41), the natural state is characterised by the possession of special privileges, notably access to economic rents, by a dominant coalition of elites. Violence among the elites is limited because they know that the organisations they are using for the extraction of rents from land, labour and capital all depend on the support of the state. The balance among the elites is inherently fragile, since external shocks or the unintended 
consequences of agreed policies may lead to distortions of the balance among interests and hence infighting among elites. Open access orders are understood as orders where, in a Weberian sense, the state has the monopoly on the legitimate use of violence, and economic and social relations are no longer personalistic but become 'impersonal' (North et al., 2009: 21-25, 112-117). Open access orders are the result of a 'transition', which can take place when elites 'find a common interest in transforming some elite privileges into impersonal elite rights shared by all members of the elite' (North et al., 2009: 190). North et al. define three so-called 'doorstep conditions' that develop in the natural state and lead to a transition to an open access order: the creation of a rule of law for elites, the opportunity to establish stable impersonal organisation, and control of the military (North et al., 2009: 26, 154-181).

\section{Contemporary manifestations of the dependency and world-system approach}

On a similar note as was made above on the modernisation approach, the fact that the writings of dependency and world-system scholars were criticised did not result in the disappearance of the approach. Contemporary research reflecting the dependency and worldsystem approach is still very visible. ${ }^{4}$ The global financial crisis even seems to have resulted in a revival of the critical analysis of worldwide capitalism that has always been the hallmark of this approach. This section discusses three examples of the contemporary influence of the dependency and world-system approach: Castells and Laserna's discussion of the new dependency inherent in global technology, recent world-system scholarship on commodity chains, and Christopher Chase-Dunn et al.'s analysis of the global crisis since 2008.

With certain regularity, scholars have returned to the idea of dependency to argue that particular forms of relations in the contemporary global capitalist system reflect forms of 'new' or 'neo' dependency'. Castells and Laserna's analysis of new forms of dependency deriving from the application of modern technologies is a typical example of the application of classical notions of dependency theory to new areas. According to Castells and Laserna (1989: 536), the application of information technologies in production processes, coupled with the dynamics of economic globalisation and socio-economic restructuring in the core and periphery have produced new forms of dependency. Technological dependency has, in

\footnotetext{
${ }^{4}$ An important element in the visibility of world-system theory is the existence of two journals dedicated to publishing research findings of scholars working in the approach. Review, the journal of the Fernand Braudel Center for the Study of Economies, Historical Systems, and Civilizations, was founded by Immanuel Wallerstein in 1977. The Journal of World-Systems Research was established by Christopher Chase-Dunn in 1994 as an open-access journal and has been an official journal of the American Sociological Association since 2009.
} 
their view, had major impacts on the countries in the global South, such as those in Latin America. According to Castells and Laserna (1989: 539), '[w]ithout a minimum level of endogenous productive capacity in hightechnology capital goods, countries must import almost all the new productive machinery in a period of rapid technological change'. Importation of sophisticated technology requires increased exports of manufactured goods, particularly those with lower technological content - and this produces a 'new unequal exchange in the international economy ... between goods and services with different technological components' (Castells and Laserna, 1989: 540).

Notions of unequal specialisation have also been traditional concerns related to the notion of global commodity chains that was pioneered by scholars working in the world-system tradition. ${ }^{5}$ In the original use of the term by Hopkins and Wallerstein (1986: 159), '[t]he concept "commodity chain" refers to a network of labor and production processes whose end result is a finished commodity. In building this chain we start with the final production operation and move sequentially backward ... until one reaches primarily raw material inputs.' A 2014 special issue of the Journal of World-Systems Research has provided an assessment of the political economy of commodity chains, more in particular of 'the way in which commodity chain analysis can be mobilized to illuminate the contours, composition, and character of the modern world-system' (Bair, 2014: 2). The contributors analyse a range of contemporary issues related to the functioning of commodity chains, from the impact of inter-state rivalry between the US and China on the governance of the transnational cotton commodity chain to gendered divisions of labour in the commodity chain, and the value generated in the production and marketing of iPads by Apple.

Amy Quark (2014) argues, in relation to the example of the transnational commodity chain of cotton, that the divide between state governance and private-sector governance is much less pronounced than often pretended. The US-dominated cotton industry attempted, together with US government agencies, to withstand the challenges to US hegemony in setting standards for cotton production: according to this analysis, the US government with transnational firms tried 'to persuade others involved in the transnational cotton trade around the world to support their governance arrangements before the Chinese state and textile manufacturers in China developed the scientific, technological and institutional capacities to launch their own hegemony-building campaign, which would be backed by the coercive

\footnotetext{
${ }^{5}$ The roots of this approach are in the work by Hopkins and Wallerstein (1986) and Gereffi and Korzeniewicz (1994).
} 
power of being the largest cotton market in the world' (Quark, 2014: 50-51). Despite the rise of China and the challenge to US hegemony, the US government and US cotton producers, in alliance with European and US transnational merchants, managed to keep Chinese influence on standard setting to a minimum and give only limited concessions to China (Quark, 2014: $52-53)$.

In the spirit of dependency and world-system theory, contemporary research into commodity chains also focuses on the way in which transnational mechanisms that support surplus creation have differential effects throughout the world-system and serve to maintain inequalities. As a witness to this orientation, Dunaway's (2014) research focuses on the role of women in transnational commodity chains. She argues that much of mainstream work on production creates a 'false analytical divide between household and market' (Dunaway, 2014: 71). Non-waged and unfree forms of labour are disproportionally done by women, although their invisible, since not-counted, contribution to the household and care for children is often not included in official calculations (Dunaway, 2014: 73-75). In a similar way, Clelland's research on the production of iPads focuses on the flow of value in the commodity chain that has been created for the production of Apple's tablets. Clelland argues that two types of value need to be taken into account: visible, monetised or 'bright' value and hidden or 'dark' value. 'Dark' value derives from 'hidden inputs in the form of externalised costs that often contribute to create value than the visible elements' (Clelland, 2014: 86). By applying a commodity-chain analysis to the production of iPads, Clelland claims that Apple's value extraction is the result of its dominance of the chain from producers through to marketing and sales (Apple's monopoly position within the commodity chain) but, very importantly, also of the company's 'monopsonistic externalisation of costs' (Clelland, 2014: 94). Apple derives substantial 'dark' value from such sources as the exploitation of Chinese migrant workers, undercompensated waged labour, unpaid household labour, informal sector labour and ecological externalities (Clelland, 2014: 95-103). Following central class-oriented elements in dependency and world-system approaches, Clelland (2014: 105) concludes that 'most of the appropriate dark value is realized, not as corporate profit, but as consumer surplus in the form of cheaper goods. ... In this manner, core citizens become a global consumerist aristocracy'.

The contributions to the symposium on the crisis in the global system since 2008 in the Journal of World-Systems Research reflect the core tenets of world-system theory, which are to interpret global issues as part of the long-term evolution of the world capitalist economy. Chase-Dunn (2013: 176-179) analyses five interlinked crises in the contemporary world- 
system (in global governance, inequality and democracy, the biosphere, the global capitalist system and the global left) as the outcome of the dialectics related to the sequence of hegemonies in the system. He argues that the U.S. hegemony - understood as the political and economic preponderance of a great power - has been on the decline for several decades. In his view, the interconnections among the crises are likely to result in a 'new stage of capitalism' (Chase-Dunn, 2013: 179). According to Sassen (2013), the crisis of capitalism has resulted in the 'expulsion' of people from the economy in large parts of the world. In her view, the deepening of global capitalism - which has replaced earlier waves of expansion into new parts of the world - requires the natural resources of large parts of the developing world, rather than their populations. These populations are increasingly expelled to the urban areas or, as migrants, to other countries, and they end up as underclasses (Sassen, 2013: 199).

Other continuing elements in the world-system approach - resistance and repression - are presented by Reifer (2013) and Robinson (2013) in their analyses of antisystemic movements and the coming into being of a global police state. Resistance, in the form of antisystemic (or anti-capitalist) movements, has gained prominence as a consequence of the Great Recession, but this should not, according to Reifer, be interpreted as a new form, but as a continuation of earlier instances of antisystemic action. In his view, the same persistent 'structural worldsystemic factors' have been responsible for the seemingly different antisystemic forces manifested in the World Social Forum, the Arab Spring and Occupy Wall Street (Reifer, 2013: 187). Repression is, according to Robinson (2013: 193), an evitable outcome of the current crisis of capitalism given 'transitions from social welfare to social control states around the world'. Overaccumulation and rising inequalities within and across societies have resulted in increased polarisation, which may no longer be governable by consensual policy making and hence may require the 'policing' of global capitalism (Robinson, 2013: 196).

\section{Concluding remarks}

This chapter has described modernisation and dependency theory as the two most important classical approaches to development. The approaches have evolved since the 1950s and 1960s as anchor points in the debate on how to best understand international development processes. The distinction made by modernisation theorists between 'traditional' and 'modern' forms of society, politics and the economy led to analyses of the circumstances and policies that were supposed to lead countries on the path to higher levels of development. Dependency theory's focus on the long-term historical processes that were locking in the progress in the countries of the global South produced analyses of the impact of colonialism 
and the persistent forms of neo-imperialist exploitation that characterise the contemporary international political economy.

Modernisation and dependency theories both were the subject of profound criticism, directed at their core messages. The modernisation approach was attacked because of its tendency to treat the Western experience as benchmark for developments in other parts of the world. The ethnocentric character of its analyses and recommendations led to a declining interest in modernisation theory among development scholars. In a similar way, dependency theory was criticised because of its perceived deterministic character, which was felt to overemphasise the barriers for developing countries in achieving a meaningful level of development.

The observed weaknesses of modernisation and dependency theories have not resulted in the complete disappearance of the research programmes they formulated four or five decades ago. While its coverage of the literature has necessarily been limited, this chapter has argued that many scholars have remained inspired by the intellectual agenda of the modernisation and dependency approach. In important ways, contemporary analysts of development have distanced themselves from the early tenets of the two approaches, which are seen either as too dogmatic or simplistic. Although it is generally critical of unilinear thinking, current research on such diverse issues as democratisation (Inglehart, 1997; Inglehart and Welzel, 2009), globalisation and modernity (Eisenstadt, 2002), anti-Westernism (Buruma and Margalit, 2004) and long-term socio-economic transformation (North et al., 2009) shows the influence of a generic modernisation paradigm. In a similar way, the criticism of dependency theory's determinism is embraced by contemporary world-system analysts. Yet, adherents of worldsystem analysis who study issues such as technological change (Castells and Laserna, 1989), the nature of international commodity or value chains (Clelland, 2014; Dunaway, 2014; Quark, 2014) or the crisis-ridden character of contemporary society (Chase-Dunn, 2013; Reifer, 2013, Robinson, 2013; Sassen, 2013) continue to be inspired by a materialist worldview that places the persistence and reproduction of inequalities centrally.

\section{Bibliography}

Almond, G. A. (1960) 'Introduction: A Functional Approach to Comparative Politics', in G.A. Almond and J.S. Coleman (eds) The Politics of the Developing Areas (Princeton: Princeton University Press): 3-64. 
Amin, S. (1974) Accumulation on a World Scale: A Critique of the Theory of Underdevelopment, 2 vols. (New York: Monthly Review Press).

Amin, S. (1987) 'Democracy and National Strategy in the Periphery', Third World Quarterly 9(4): 1129-1156.

Amin, S. (1990) Delinking: Towards a Polycentric World (London: Zed Books).

Almond, G.A. and Coleman, J.S., eds (1960) The Politics of the Developing Areas (Princeton: Princeton University Press).

Blair, J. (2014) 'Editor's Introduction: Commodity Chains in and of the World-System', Special Issue on the Political Economy of Commodity Chains, Journal of World-Systems Research 20(1): 1-10.

Braudel, F. (1992) Civilisation and Capitalism, 15th-18th Century, vol. 3: 'The Perspective of the World' (Berkeley: University of California Press).

Buruma, I. and Margalit, A. (2004) Occidentalism: A Short History of Anti-Westernism (London: Atlantic Books).

Cardoso, F.H. (1972) 'Dependency and Development in Latin America', New Left Review I/74: 83-95

Cardoso, F.H. and Faletto, E. (1979) Dependency and Development in Latin America (Berkeley: University of California Press).

Castells, M. and Laserna, R. (1989) 'The New Dependency: Technological Change and Socioeconomic Restructuring in Latin America', Sociological Forum 4(4): 535-560.

Chase-Dunn, C. (2013) 'Five Linked Crises in the Contemporary World-System', Symposium on The Global System since 2008: Crisis of What?, Journal of World-Systems Research 19(2): 175-181.

Clelland, D. (2014) 'The Core of the Apple: Degrees of Monopoly and Dark Value in Global Commodity Chains', Special Issue on the Political Economy of Commodity Chains, Journal of World-Systems Research 20(1): 82-111.

Dunaway, W. (2014) 'Bringing Commodity Chain Analysis back to its World-Systems Roots: Rediscovering Women's Work and Households', Special Issue on the Political Economy of Commodity Chains, Journal of World-Systems Research 20(1): 64-81.

Eisenstadt, S.N. (2002) 'Multiple Modernities', in S.N. Eisenstadt (ed.) Multiple Modernities (New Brunswick: Transaction Publishers): 1-29.

Frank, A.G. (1969) Latin America: Underdevelopment or Revolution. Essays on the Development of Underdevelopment and the Immediate Enemy (New York: Monthly Review Press). 
Frank, A.G. (1972) Lumpenbourgeoisie: Lumpendevelopment. Dependence, Class and Politics in Latin America (New York: Monthly Review Press).

Frank, A.G. (1979) Dependent Accumulation and Underdevelopment (New York: Monthly Review Press).

Frank, A.G. (1984) Critique and Anti-critique: Essays on Dependence and Reformism (London: Macmillan).

Gereffi, G. and Korzeniewicz, M., eds (1994) Commodity Chains and Global Capitalism (Westport: Praeger).

Higgott, R.A. (1983) Political Development Theory (London: Croom Helm).

Hopkins, T.K.. and Wallerstein, I. (1986) 'Commodity Chains in the World-Economy Prior to 1800 ', Review 10(1): 157-170.

Hoselitz, B.F. (1960) Sociological Aspects of Economic Growth (Glencoe: The Free Press).

Huntington, S.P. (1968) Political Order in Changing Societies (New Haven: Yale University Press).

Inglehart, R. (1971) 'The Silent Revolution in Europe: Intergenerational Change in PostIndustrial Societies', American Political Science Review 65(4): 991-1017.

Inglehart, R. (1997) Modernization and Postmodernization: Cultural, Economic, and Political Change in 43 Societies (Princeton: Princeton University Press).

Inglehart, R. and Welzel, C. (2009) 'How Development Leads to Democracy: What We Know about Modernization', Foreign Affairs 88(2): 33-48.

Kay. C. (2011) Latin American Theories of Development and Underdevelopment (Abingdon: Routledge).

Nederveen Pieterse, J. (2010) Development Theory: Deconstructions/Reconstructions, $2^{\text {nd }}$ ed. (London: Sage).

North, D.C., Wallis, J.J. and Weingast, B.R. (2009) Violence and Social Orders: A Conceptual Framework for Interpreting Recorded Human History (Cambridge: Cambridge University Press).

Parsons, T. (1951) The Social System (New York: The Free Press).

Parsons, T. (1960) Structure and Process in Modern Societies (Glencoe: The Free Press).

Parsons, T. (1964) 'Evolutionary Universals in Society', American Sociological Review 29(3): 339-357.

Quark, A. (2014) 'Private Governance, Hegemonic Struggles, and Institutional Outcomes in the Transnational Cotton Commodity Chain', Special Issue on the Political Economy of Commodity Chains, Journal of World-Systems Research 20(1): 38-63. 
Reifer, T. (2013) 'Occupy Wall Street, the Global Crisis, and Antisystemic Movements: Origins and Prospects', Symposium on The Global System since 2008: Crisis of What?, Journal of World-Systems Research 19(2): 186-192.

Robinson, W.I. (2013) 'Policing the Global Crisis', Symposium on The Global System since 2008: Crisis of What?, Journal of World-Systems Research 19(2): 193-197.

Ross, E.B. (1998) 'Cold Warriors without Weapons', Identities: Global Studies in Culture and Power 4(3-4): 475-506.

Rostow, W.W. (1960) The Stages of Economic Growth: A Non-communist Manifesto (Cambridge: Cambridge University Press).

Sassen, S. (2013) ‘Expelled: Humans in Capitalism's Deepening Crisis', Symposium on The Global System since 2008: Crisis of What?, Journal of World-Systems Research 19(2): 198-201.

Wallerstein, I. (1974) The Modern World-System: Capitalist Agriculture and the Origins of the European World-Economy in the Sixteenth Century (New York: Academic Press).

Wallerstein, I. (1979) The Capitalist World-Economy (Cambridge: Cambridge University Press).

Wallerstein, I. (1984) The Politics of the World-Economy: The States, the Movements, and the Civilizations (Cambridge: Cambridge University Press).

Wallerstein, I. (2000) 'Globalization or the Age of Transition? A Long-Term View of the Trajectory of the World System', International Sociology 15(2): 251-267. 


\section{On the contributor}

Wil Hout is Professor of Governance and International Political Economy at the International Institute of Social Studies of Erasmus University Rotterdam. A political scientist by training ( $\mathrm{PhD}$ Leiden, 1992), he has specialised in the analysis of governance reform and development assistance policies. Articles have appeared in such journals as the European Journal of International Relations, Development and Change, the Journal of Development Studies, Development Policy Review and Third World Quarterly. His most recent book is Political Economy and the Aid Industry in Asia, co-authored with Jane Hutchison, Caroline Hughes and Richard Robison (Palgrave Macmillan, 2014). 


\begin{abstract}
Classical approaches to development: Modernisation and dependency

This chapter discusses modernisation and dependency theory as the two central, classical approaches to international development. Modernisation theory distinguishes between 'traditional' and 'modern' forms of society, politics and the economy and studies the circumstances and policies that are supposed to contribute to higher levels of development. Dependency theory focuses on the limits that historical relationships, often deriving from colonialism, place on the development of poor countries. Modernisation theory was criticised severely for its perceived emphasis on the Western experience as a guide for countries in the South. Dependency theory was criticised because it overemphasised the barriers for development in developing countries. Many contemporary scholars are still inspired by ideas derived from modernisation and dependency theory. The chapter discusses studies on democratisation and long-term socio-economic transformation as examples of the influence of modernisation theory, and studies on international commodity chains and the nature of the current crisis in relation to the lasting impact of dependency theory.
\end{abstract}

